\title{
Dünya Klasmanında Üretim Kapsamında İş Sağlı̆̆ı ve Güvenliği Çalışmalarına Yönelik Bir Model Önerisi ve Uygulama
}

\author{
Esin Tuba TEPEKULE* ${ }^{*}$ Şevkinaz GÜMÜŞOĞLU**
}

\begin{abstract}
$\ddot{O Z Z}$
Her uygulama ve operasyonda en iyi olmayı ve içinde barındırdlğg her stratejiyi mükemmel düzeyde gerçekleştirmeyi hedefleyen yaklaşım son yıllarda Dünya Klasmanında Üretim (WCM) olarak anılmaktadır. WCM'nin içinde barındırdığ uygulama ve stratejilerin sinerjik etkisi, işletmelerin gücünü mevcut yoğun rekabet ortamında, istenen seviyeye çıkarmada yardımcı olacaktır.

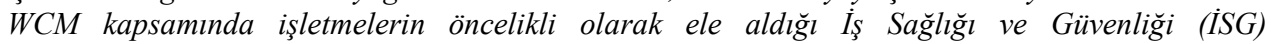
uygulamalarında üst seviyede performans göstermeleri, günümüz işletmelerini rakiplerinden bir adım öteye götürerek en iyi olmalarına katkı sağlayacaktır. Bu anlamda Dünya Klasmanında İs Sağlı̆̆l ve Güvenliğinin (World Class Safety-WCS) başarısını güvenlik kültürü, ISSG liderliği, güvenlik programı ve güvenlik performansı elemanlarının bir fonksiyonu olarak tanımlayan Larry Hansen'in modeli çalışmamızın referans noktası olmuştur. Ele alınan modelden hareketle çalışmada Ege Bölgesi Sanayi Odası'nın belirlediği Türkiye'nin en büyük 500 sanayi kuruluşu listesinden belirli bir bölge içinde kalan işletmelerde, WCS bileşenlerinin WCS başarısına etkisinin incelenmesi amaçlanmıştır.
\end{abstract}

Anahtar Kelimeler: Dünya Klasmanında Üretim, Dünya Klasmanında ISSG, Dünya Klasmanında ISG Bileşenleri

JEL Siniflandirmast: M11, L60, J28

\section{A Model Proposal and Implementation Concerning Occupational Health and Safety within the Framework of World Class Manufacturing}

\begin{abstract}
The approach, which aims at becoming the best in every application and operation realizing every strategy that it has at a perfect level, has been referred to as World Class Manufacturing (WCM). The synergic effect of WCM inherent in application and strategies will be helpful in taking businesses' strength to the desired level in the current competitive environment. For businesses in applications of Occupational Health and Safety $(\mathrm{OHS})$ to perform at the top level will contribute to become the best, taking one step forward from its competitors. In this sense, Larry Hansen's model, which defines the success of World Class Safety (WCS) as the function of safety culture, operational leadership, safety program and performance, has been a reference point for this study. Taking this model as the basis, in this study, it is aimed to scrutinize the effect of WCS constituents' in a certain area of the businesses from the list of top 500 industrial firms in Turkey set for the year 2012 by the Aegean Region Chamber of Industry.
\end{abstract}

Safety

Key Words: World Class Manufacturing, World Class Safety, Components of World Class

JEL Classification: M11, L60, J28

*Dr. İşletme Bilim Doktoru, etubaakgunduz@ hotmail.com
${ }^{*}$ Prof. Dr., Yaşar Üniversitesi, İBF, İşletme Bölümü, sevkinaz.gumusoglu@ yasar.edu.tr
(Makale Gönderim Tarihi: 09.02.2016/ Yayına Kabul Tarihi: 13.03.2017)

Doi Number: 10.18657/yonveek.307510 


\section{GİRIŞ}

İşletmenin varlığını sürdürebilmesi ve rekabet gücünü sürdürülebilir bir seviyede tutarak her alanda en iyi olabilmesi için; iç ve diş çevresinde meydana gelen her türlü gelişime ve değişime hızlı cevap verebilmesi, değişime kolay adapte olabilmesi, hep bir adım önde olması daha net bir ifade ile rekabetçi bir işletme olması şarttır. Bir işletmenin rekabet edebilmesi ve rekabetçi bir işletme olabilmesi için temelde; kendisine rakip olacak bir işletmeye, bu rekabeti yürütebilmesini sağlayacak bir çevreye ve mutlak üstünlük sağlayacak bir ve/veya birkaç yeteneğe ihtiyacı vardır. Bu yetenekler işletmeye rekabet avantajı sağlayarak onun rekabetçi olmasını ve bu durumu sürdürebilmesini sağlamaktadır.

Bir adım önde olmak, oluşabilecek firsat ve tehditleri önceden tahmin ederek işletmenin olası kazanç ve kayıplarını değerlendirmek anlamına gelmektedir. Bir adım önde olma, mükemmellik yolunda işletmenin varlığının sürdürülebilir olması için gerekli olmakla birlikte tek başına yeterli değildir. $\mathrm{Bu}$ nedenle bir adım önde olmanın yanında işletmelerin her alanda en iyi olma isteğine sahip olması, işletmenin varlığını etkin bir şekilde devam ettirebilmesi için çok önemlidir.

Varlığını etkin bir şekilde idame ettirebilen işletmeler, bu konuda sürekliliği sağlamak adına, müşterilerinin isteklerini ön planda tutacak; ürünün tasarımından müşterisine ulaşıncaya kadar ki bütün süreçlerinde hep en iyi olmak isteyecektir. Başka bir ifadeyle "En iyi olma" kaygısı; işletmelerin sahip oldukları kültürü, varlık ve değerleri sürekli olarak gözden geçirmelerine neden olmakta; eksiklerini tamamlamalarını, her alanda iyileştirme çabası içinde olmalarını sağlamaktadır. İşletmelerin en iyi olma arzusu ve en iyi olma durumunun sürekliliğini sağlama isteği, işletmeleri mükemmellik arayışı ile karşı karşıya bırakmıştır. Bu açıdan bakıldığında her alanda en iyi olmak düşüncesi; işletmeleri ve dolayısıyla çalışanlarını, kendilerine rekabet üstünlüğü sağlayarak en iyi olma hedefine ulaştıracak çeşitli stratejilere ve felsefelere yöneltmiştir. Son yıllarda anılmaya başlanan ve yapılan her uygulama ve stratejide en iyi sonucu elde ederek hedeflemeyi ilke edinmiş olan yaklaşım Dünya Klasmanında Üretim olmuştur.

Bu çalışmada dünya klasmanında üretim hakkında bilgi verilmiş, dünya klasmanında üretim kapsamında değerlendirilen ve birinci önceliğe sahip olan iş sağlığı ve güvenliği uygulamalarına ilişkin öne sürülen modelin bileşenleri incelenmiş ve bu bileşenlerin iş sağlığı ve güvenliği çalışmalarının başarısına etkisi ortaya konulmaya çalışılmıştır.

\section{DÜNYA KLASMANINDA ÜRETIM}

En iyi olma içgüdüsüyle hareket eden işletmeler birçok uygulama ve stratejiyi kullanarak elde edecekleri rekabet avantajını sürdürülebilir kılmayı hedefler. Teoride ve uygulamada yer alan en iyi uygulamaların işletmenin bütün fonksiyonlarında uygulanması ve bunların sürekliliğinin işletmede bir standart haline gelmesi, bu vizyona sahip olan işletmeyi dünya klasmanına taşıyacaktır. $\mathrm{Bu}$ çerçevede sürekli iyileştirme anlayışına hizmet eden ve işletme için en uygun strateji demetini sunan en iyi uygulamalar bütünü Dünya Klasmanında Üretim (World Class Manufacturing -WCM)'dir. 
Günümüz koşullarında, işletmelerin içinde bulunduğu rekabetçi çevre ve her alanda en iyi olma isteği, WCM'ye olan ilgiyi artırmıştır. WCM, dilimize "Dünya klasmanında üretim”, "dünya sınıfında üretim", "alanında en iyisi” ve "en iyi uygulamalar" gibi farklı şekillerde tercüme edilmektedir. Kimi yazarlar WCM'yi bir yönetim stratejisi (Haynes, 1999; Voss, 1995), kimi yazarlar da bir üretim stratejisi (Lind, 2001; McNair v.d., 1989) olarak ele almaktadır. Buna karşın birçok yazara göre de WCM, bir teknikten ziyade bir yönetim felsefesi (Schonberger, 1986; Maskell, 1991) olarak tanımlanmaktadır. Bu çalışmalar 1şı̆̆ında literatürde WCM'nin strateji veya felsefe olup olmaması konusunda ortak bir kanıya varılamamış olduğu aşikârdır.

WCM'ye ilişkin literatürde üzerinde uzlaşılmış net ve kesin bir tanımlama da bulunmamaktadır. WCM ilk kez 1984 yılında Hayes ve Wheelwright tarafindan, eş zamanlı mühendislik, yalın üretim ve kaliteden oluşan en iyi uygulamaları içinde barındıran rekabetçi bir strateji olarak tanımlanmıştır (Fullerton ve McWatters,2004:87). Bu tanımdan hareketle WCM işletmelerini; müşteri taleplerine hızlı cevap veren, yüksek otomasyona sahip, üretimi kısa sürelerde gerçekleştiren, çalışan katılımına önem veren, yalın anlayışın hakim olduğu, takım çalışmasını teşvik eden, eğitimi ön planda tutarak proaktif bir zihniyetle faaliyette bulunan işletmeler olarak betimlemek mümkündür.

İşletmelerin içinde bulundukları dinamik çevre koşullarında hayatta kalmayı başarıp takip edilen (lider) olmaları için her şeyden önce öğrenen ve öğrendiklerini uygulayabilen bir yapıya sahip olmaları gerekmektedir. İşletmelerin küresel anlamda rekabet edebilmesini ve rekabet gücünü sistematik olarak iyileştirebilmesini sağlayacak uygulamalar bütünü, WCM'yi işaret etmektedir. İyi tanımlanmış yollara sahip bir iyileştirme yolculuğu, dünya klasmanında üreticileri başarıya götüren en önemli araçtır. Bu nedenle WCM uygulamalarının amacına ulaşabilmesi için birtakım stratejiler sürekli iyileştirme konsepti içerisinde değerlendirilmelidir. Ancak bu noktada üzerinde uzlaşılmış ve her işletme için uygulanabilecek tek bir stratejiden veya sürekli iyileştirme konseptinden söz etmek pek mümkün değildir. $\mathrm{Bu}$ bağlamda literatürde farklı yazarlar tarafından değerlendirilen WCM stratejileri literatürden derlenerek Tablo 1'de toplu olarak gösterilmiştir:

Tablo 1:WCM Stratejileri

\begin{tabular}{|l|l|l|}
\hline YAZAR & YIL & \multicolumn{1}{|c|}{ Geliştirilen/Uygulanan WCM Stratejileri } \\
\hline (Maskell) & 1991 & $\begin{array}{l}\text { Ürün kalitesine yeni bir yaklaşım } \\
\text { Tam Zamanında Üretim } \\
\text { Müşteri ihtiyaçlarına esnek yaklaşım } \\
\text { İşgücü yönetimindeki değişimler }\end{array}$ \\
\hline (Steinbacher \& Steinbacher) & 1993 & $\begin{array}{l}\text { Toplam Çalışan Katılımı } \\
\text { Toplam Kalite Yönetimi (TKY) } \\
\text { Toplam Üretken Bakım (TPM) } \\
\text { Tam Zamanında Üretim (JIT) }\end{array}$ \\
\hline $\begin{array}{l}\text { (Roth \& Miller) Kalite kontrol } \\
\text { (Cua, McKone, \& Schroeder) }\end{array}$ & 1992 & $\begin{array}{l}\text { TKY Fabrika otomasyonu } \\
\text { JIT } \\
\text { TPM } \\
\text { Bilgalşan katılımı } \\
\text { Üretim }\end{array}$ \\
\hline
\end{tabular}


E. T. Tepekule \& Ş. Gümüşoğlu / Dünya Klasmanında Üretim Kapsamında İş Sağllğı ve Güvenliği Çalışmalarına Yönelik Bir Model Önerisi ve Uygulama

\begin{tabular}{|c|c|c|c|}
\hline (Rubrich \& Watson) & 2004 & $\begin{array}{l}5 \mathrm{~S} \\
\text { Takım kurma } \\
\text { TPM } \\
\text { Üretim Hücreleri }\end{array}$ & $\begin{array}{l}\text { Kaizen } \\
\text { SMED } \\
\text { Kanban }\end{array}$ \\
\hline $\begin{array}{l}\text { (Mylnek, Vonderembse, Rao, \& } \\
\text { Bhatt) }\end{array}$ & 2005 & $\begin{array}{l}\text { Çalışan gelişimi } \\
\text { TKY } \\
\text { Tedarikçi gelişimi }\end{array}$ & $\begin{array}{l}\text { JIT } \\
\text { Ürün gelişimi } \\
\text { Müşteri odaklılık }\end{array}$ \\
\hline (McLeod) & 2008 & $\begin{array}{l}\text { Örgüt ve kültür } \\
\text { Lojistik } \\
\text { Üretim sistemleri ( }\end{array}$ & tim, süreç tasarımı, TKY) \\
\hline
\end{tabular}

Yukarıda Tablo 1'de yer alan farklı yazarlar tarafindan ileri sürülen ve farkl stratejiler temelinde uygulanan/geliştirilen WCM'yi, devamlılık arz eden sürekli iyileştirme anlayışıyla birlikte stratejileri eş zamanlı ve bir bütün olarak değerlendirmek daha doğru bir yaklaşım olacaktır. Bu yaklaşımı durum tespiti, yapılacak çalışmalar ve denetim aşamalarından oluşan WCM planı ile açıklamak mümkündür (Sakamoto,2010:36) :

- Bu kapsamda WCM'yi uygulamayı düşünen bir işletme öncelikle mevcut durumunu değerlendirmelidir. İşletme bunun için SWOT analiziyle zayıf yanlarını tespit etmelidir. Fonksiyon, süreç ve aktiviteleriyle birlikte mevcut sistemini gözden geçirip, performans ölçümleriyle birlikte dokümantasyonunu sağlamalıdır. Fabrika temizliğinden, tesis güvenliğine; eğitime katılım sağlanmasından atölyeden fikir elde etmeye kadar bütün noktalar kontrol edilmeli ve işletmenin o anının fotoğrafı çekilmelidir.

- Yapılan durum tespitlerinden hareketle işletmenin nerede olduğu ve nerede olması gerektiği tanımlanmalıdır. WCM performans standartlarına bağlı olarak vizyon ve misyon geliştirilmelidir. WCM amaçlarına ve işletmenin pozisyonuna uygun olarak, sürecin sağlıklı bir şekilde ve istenilen yönde ilerlemesini sağlayacak uygun değişim önlemlerini alma faaliyetlerini içeren stratejiler geliştirilmelidir. Ölçüm tabanlı yönetim anlayışı ve uygulamalarını içeren ve WCM sürecine zemin oluşturacak stratejiler hazırlanmalıdır.

- WCM ile elde edilen durumu korumak için, modelin sürekliliği sağlanmaya çalışılmalıdır. Gerekli denetimler ve karşılaştırmalar yapılarak en iyi olma yolundaki çabaların sonuçları değerlendirilmelidir.

WCM planı kapsamında uygulanacak ve işletmelerin dünya klasmanı seviyesine çıkmasını sağlayacak olan stratejileri; $6 \mathrm{~S}$ stratejisi, takım kurma, dünya klasmanında bakım (WCMt), tekli dakikalarda kalıp değişimi (SMED), kanban, kaizen ve dünya klasmanında iş sağlığı ve güvenliği olarak sıralamak mümkündür. WCM'yi sağlam temeller üzerinde oturtabilmek ve en iyi uygulamaları gerçekleştirebilmek; işletmenin fiziksel olarak da en iyi çalışma koşullarına sahip olmasını gerektirmektedir. Bu nedenle, 6 S stratejisi WCM uygulamaları için iyi bir başlangıç noktasıdır.

Hiroyuki Hirano tarafından Japon üretim işletmeleri için geliştirilen $5 \mathrm{~S}$ Stratejisi, Japon örgütleri ve ev idaresi sistemini temel alarak ortaya çıkarılmıştır. Geleneksel olarak beş eleman içermesine rağmen birçok işletme, işyeri örgütsel sisteminin önemli bir parçası olarak güvenlik (Safety) elemanını da bu stratejiye eklemeyi uygun görmüş ve bunun sonucunda strateji, ayıklama, düzenleme, 
temizlik, standartlaşma, disiplin ve güvenlik elemanlarıyla $6 \mathrm{~S}$ olarak anılmaya başlamıştır (Creative Safety Supply, 2010). İşletme fiziksel koşullarını bu stratejiyle yeniden biçimlendirirken, ortaya çıkacak zincirleme faydaları zaman içerisinde gözlemleyebilecektir. $\mathrm{Bu}$ stratejinin doğru ve etkin bir şekilde uygulanması ile birlikte işyerindeki karmaşa ve düzensizlik ortadan kalkacak; işyerine görsel ve kullanışlı bir düzen hakim olacak; çalışanlar ekipmanlara istedikleri anda ve kolaylıkla ulaşabilecek; gereksiz eforlardan kaçınarak motive olmaları sağlanacaktır. Bunun yanında ekipman bakım ve onarım kaynaklı üretim durmaları, oluşabilecek tehlikeli durum ve davranışlar azalacaktır. Dolayısıyla WCM evinde istenen performans hedeflerine ulaşılması kolaylaşacaktır.

İşyerinin temizliği ve düzeninden sonra çalışanların tüm süreçlere tam katılımı ve takım çalışmasının gerekliliği ortaya çıkmaktadır. Üst yönetimden alt düzey çalışana kadar tüm çalışanların; eğitim, iletişim ve bilgi akışı faaliyetlerini etkin ve verimli bir şekilde yerine getirebilmesinin kolay yolu takımlarla çalışmaktır. Dünya klasmanında üretim seviyesine erişebilmek için stratejileri uygulayacak çalışanların takım çalışmasıyla ortaya çıkaracağı sinerjiye ihtiyaç duyulmaktadır. Bu sinerji ve sinerjinin getirilerini elde edebilmek, uygulanacak stratejilerin en iyi şekilde yapılmasına olanak tanıyarak en iyi performansı elde etmeye katkıda bulunacaktır.

Bütün WCM stratejilerinin temelini teşkil Toplam üretken bakım, organizasyonel fonksiyonlar özellikle de üretim-bakım, ürün kalitesini sürekli iyileştirme, operasyonel etkinlik, kapasite güvencesi ve güvenlik arasındaki sinerjistik ilişkiyi tanımlamaktadır (Sun vd., 2003:225). Bazı yazarlar tarafından "israfsız bakım", "bakımda mükemmellik", "dünya sınıfı mükemmellik" veya "en iyi bakım uygulaması" olarak isimlendirilen dünya klasmanında bakım, çeşitli işletmelerin dünya klasmanında üreticiye dönüşmek için bakımda takip ettiği ve kendi üretim sürecine adapte ettiği en iyi uygulamalar olarak tanımlanmaktadır Stratejik bir kapasite olarak yorumlanan dünya klasmanında bakım; tamamlayıcı ekipman yönetimi ve tamamlayıcı ekipman yönetimi sayesinde elde edilecek rekabet avantajı olarak işletme içinde kendini göstermektedir (Mıshra vd., 2006:143-144).

Dünya klasmanında bakımın sağlanabilmesi için SMED (Single Minute Exchange Dies) stratejisine uygulayabilmek ve on (10) dakikanın altında gerçekleştirilen kurulumları (setup) sağlayabilmek çok büyük önem taşımaktadır. SMED'in ilk aşamaları 1950'lerde Shigeo Shingo tarafından geliştirilmiştir. Setup süresi gerekli jig, aparat vs. hazırlanması, teçhizatın makineye bağlanması, teçhizatın makine üzerinde ayarlanması, deneme üretimi ve gerekirse ayarlanması şeklinde dört fonksiyondan oluşmaktadır ( Shingo, 1989:47). Bu dört fonksiyonda mükemmelliği yakalayarak setup süresindeki bütün israfları elimine etmek, setupları tek aşamalı süreçlere indirgemek ve setup süresini mümkün olduğunca sıfıra yakın hale getirmek WCM kapsamında ulaşılmak istenen amaçlar arasındadır (Rubrich ve Watson, 2004:320). WCM kapsamında hızlı ve kaliteli üretim gerçekleştirebilmek için ürün geliştirme, makinelerin ve aparatlarının hazırlama ve kurulum sürelerini mümkün olduğunca kısaltmak işletmeye karşılaşabileceği her 
türlü israfı önleme açısından ciddi bir rekabet avantajı sağlayacaktır. Bunun yanında zamanında üretim, teslim ve zamanında dağıtım ile müşteri memnuniyeti üst seviyeye çıkarmak mümkün olacaktır.

WCM mantığını pekiştirmek için Kanban sistemi tedarikçilerle birlikte süreçlerde aksama meydana gelmeden faaliyetlerin gerçekleştirilmesini sağlayarak bütünlüğü korumaktadır. Kaizen uygulaması, dünya klasmanında iş sağlığı ve güvenliği için sıfır anormallik hareketinin tam anlamıyla gerçekleştirilebilmesi adına WCM kapsamında işletmede kullanılması şart olan bir stratejidir. Bu gereklilik Kaizen uygulamasının WCM için gerekliliğini açık bir şekilde ortaya koymaktadır. Böylece yapılan iyileştirmeler WCM'nin uygulanması için kolaylık ve hız sağlayacaktır.

WCM modelinin istenen sonuçlarla gerçekleştirilmesi iş güvenliğinin hayatının vazgeçilmez bir değeri olarak ele alıp benimsenmesine bağlıdır. Benimsenen anlayışın bireysel bilinçlenmeden hareketle tüm paydaşlara yansıması ve kitlesel bir oluşum haline gelmesi işletmelerde ISG uygulamalarının ve dolayısıyla WCM stratejilerinin eniyilemesini sağlayacak altyapıyı oluşturmaktadır.

\section{DÜNYA KLASMANINDA İŞ SAĞLIĞI VE GÜVENLİ̆̆i}

WCM stratejilerinin gerçek anlamda amaçlarına ulaşabilmesi insan faktörüne bağlı olduğundan, bütün uygulamaların kaynağ dairdir. Bu açıdan ele alındığında İSG uygulamaları, dünya klasmanında yer almak isteyen işletmeler için demirbaş niteliğinde olup en fazla önemsemesi gereken uygulamalardan biridir. Çünkü çalışana gösterilen saygı ve verilen değer, işletmede kullanılan her sistemin ve sürecin çıktısında kendini kalite olarak göstermektedir. $\mathrm{Bu}$ anlamda, çalışanların ve iş ortamının sağlığını ve güvenliğini korumak ve garanti altına almak; çalışana gösterilen saygıyı ifade etmesi açısından çok önemlidir. Çalışana, işe ve işyerine zarar verebilecek olan, çeşitli nedenler sonucu oluşan olumsuz koşulları engellemek ve güvenli çalışma ortamı yaratmak amacıyla yapılması gereken planlı çalışmalara İş Sağlığı ve Güvenliği (ISSG) Uygulamaları denir. İSG uygulamalarının gerekliliği 30 Haziran 2012 tarihinde yürürlüğe giren 6331 Sayılı İş Sağlığı ve Güvenliği Kanunu ile yasalaşmış ve gerekli tüm İSG uygulamalarının yapılması yaptırımlara bağlanarak yasal bir zorunluluk haline getirilmiştir.

Dünya klasmanında yer almak isteyen işletmelerin temel değer niteliğinde olan İSG uygulamalarını Dünya Klasmanında İş Sağlığı ve Güvenliği (World Class Safety-WCS) seviyesinde gerçekleştirebilmeleri için, işletmelerin neden bu uygulamaya başvurduklarının ve neyi amaçladıklarının farkında olmaları ile en uygun ve en iyi olan sistemi kullanmaları gerekmektedir (Leeman, 2007, s. 32). Bu üç hususu dikkate alarak gerçekleştiren işletmeler, İSG uygulamalarında istenen mükemmellik seviyesine erişebilir. İSG uygulamaları ve bu uygulamaların başarısı; çalışanların motivasyonu, işe devamı ve performanslarında artış gibi konularda işletmede oluşabilecek problemleri minimuma indirir. Buna karşın İSG uygulamalarını gerçekleştirmeyen veya bu uygulamalarda başarılı olamayan işletmeler çalışan kaybı ve çalışan kaybının ortaya çıkardığı maddi zararlar, 
teçhizat ve tesiste meydana gelen maddi hasarlar, idari para cezaları gibi birçok sıkıntı yaratacak durumla karşı karşıya kalabilecektir. Kısaca işletmeler İSG uygulamalarına ve bu uygulamaların optimizasyonunu sağlayacak çalışmalara ne kadar önem verirlerse, o kadar iyi sonuçlar elde edebilirler. Bu doğrultuda israfi önleme, maliyeti azaltma ve insana saygı gibi WCM'nin temel etkilerini de içinde barındıran WCS, işletmelerin; piyasadaki rekabetçi konumlarını, kamuoyundaki saygınlıklarını ve en önemlisi çalışanlarının gözündeki imajlarını güçlendiren önemli bir etken olarak karşımıza çıkmaktadır.

$\mathrm{Bu}$ etkilerin ortaya çıkabilmesi ise her şeyden önce İSG'nin, işletmenin her bileşeninin bir parçası olarak kabul edilebilmesi ile mümkündür. Güvenliğin öncelikli olduğu bir ortam yaratmak için işletmenin en üst seviyesinden başlayarak en aşağıdaki seviyelere doğru yayılacak şekilde süreçler ve çalışma prosedürleri oluşturulmalı; ekipmanlar ve çalışanlar bu eksende bir araya getirilmelidir. Böylelikle işletmeler için WCS seviyesine ulaşmak mümkün olacaktır. Ancak günümüz dünyasında İSG, işletmeler tarafından halen yasal bir zorunluluk olarak algılanmakta ve iş güvenliği bir maliyet kalemi olarak kabul edilmektedir.

\section{DÜNYA KLASMANINDA İŞ SAĞLIĞI VE GÜVENLIĞ̈i ÇALIŞMALARINA YÖNELİK MODEL VE BİLEŞENLERİ}

WCM denetimlerinde birinci önceliğe sahip olan Dünya Klasmanında İş Sağlığı ve Güvenliği (WCS), dünya klasmanında performans elde etme amacıyla; İSG uygulamalarının sürekli iyileştirme kapsamında optimize edilmesi olarak tanımlamak mümkündür. WCS'nin temel amacı iş kazalarını sıfırlamaktır. Bu nicel gibi gözüken amacı gerçekleştirebilmek için işletmelerin, örgüt kültürüyle ilişkili olan İSG uygulamalarına yönelik nitel birtakım amaç ve ilkeleri gerçekleştirmesi gerekmektedir. Kazaların önlenebilir olduğu konusu çalışanların İSG ile ilgili zihin yapısı değiştirilerek işletmenin güvenlik kültürünün bir parçası haline getirilmelidir. Bu nitel amaca yönelik olarak örneğin, İSG eğitimlerine gereken önemin verilmesi, sıfır kaza amacına ulaşmayı sağlayacak hazırlıklardan bir tanesidir. Benzer şekilde çalışanların sadece kendi hayatlarından değil aynı zamanda çalışma arkadaşlarının da hayatlarından sorumlu olduğu ve yönetimin çalışanlarını ISG konusunda her zaman desteklemesi de bu amaca hizmet edecek çalışmalardan birkaçıdır.

İşletmelerin WCS'nin amaçlarına ulaşabilmesi için İSG faaliyetlerinde de mükemmelliği yakalaması gerekmektedir. Bunun için, İSG faaliyetlerini tam anlamıyla gerçekleştirmeyi sağlayacak fiziksel ve örgütsel ortamın sağlanması işletmeler adına öncelikli koşuldur ve bu noktada en iyi olma anlayışına sahip, katılımcı ve lider özellikleri taşıyan çalışanlar gereklidir. İşletmeler arzu edilen performans düzeyine erişebilmek için, uygun ortam koşullarında çalışanlarıyla birlikte hareket ederek, istenilen performansa yönelik olarak belirlenen programları uygulamalıdırlar. Bu programlar, çalışanları ve kullanılan sistemleri destekleyecek her türlü çalışmayı içinde barındırmalıdır.

Larry Hansen'in 2005 yılında yayımlanan ve çalışmamızın referans noktası olan "Stepping Up To Operational Safety Excellence" isimli çalışmasında, Hansen WCS başarısının İSG liderliği, güvenlik kültürü, İSG programı ve İSG performansı 
bileşenlerinin fonksiyonuna bağlı olduğunu göstermiş ve şu şekilde belirtmiştir (Hansen, 2005, s. 4).

$$
\text { WCS }=\mathbf{f}(\mathbf{K}, \mathbf{L}, \mathbf{P}, \mathbf{G})
$$

Fonksiyonda $\mathrm{K}$ güvenlik kültürünü, $\mathrm{L}$ İSG liderliğini, $\mathrm{P}$ güvenlik programını ve $\mathrm{G}$ güvenlik performansını temsil etmektedir. Bu fonksiyondan hareketle WCS bileşenleri aşağıda yer alan Şekil 1'de gösterilmiştir.

Şekil 1:Dünya Klasmanında İSG Bileşenleri

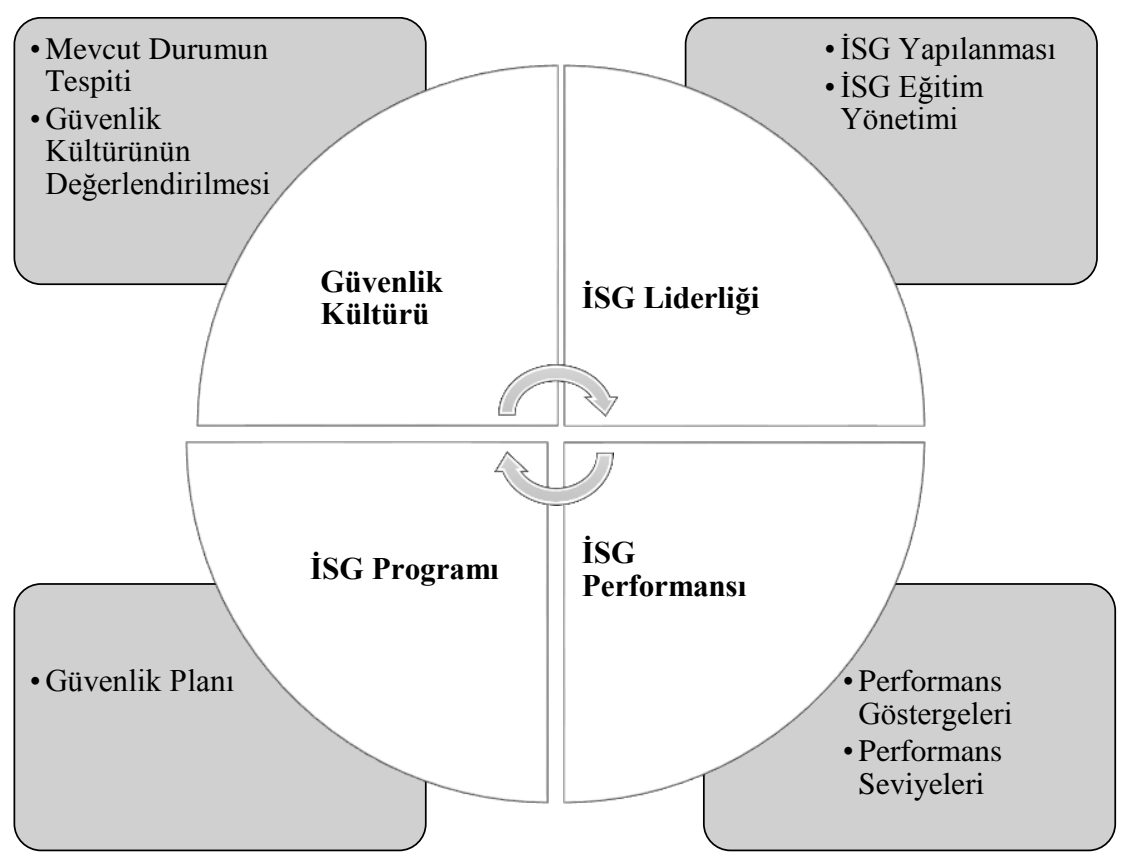

İşletmeler İSG faaliyetlerinde en iyi olmak ve mükemmelliğe ulaşmak için güvenlik kültürü, İSG liderliği, İSG programı ve yüksek performansa odaklanarak doğru ve etkin bir şekilde bu faaliyetleri tasarlamalıdır. Bunun için işletmelerin öncelikle sahip oldukları ISG yönetim sistemlerinin mevcut durumlarını iyi bir şekilde analiz etmesi gerekmektedir. Bu çerçevede İSG'nin kurumsal bir değer ve ayrı bir işletme fonksiyonu olarak ele alınması, lider ruhlu çalışanların varlığı ve katılımı, hayat boyu güvenlik anlayışıyla proaktif yaklaşımın teşviki ve desteklenmesi, etkin iletişim kanallarıyla denetimin sağlanması ve etkileşimli eğitimlerin verilmesi İSG yönetim sistemlerinde mükemmelliğe giden yolun birer basamağı olarak ifade edilebilir.

İşletmelerin dünya klasmanında İSG başarısı elde edebilmek için güvenlik kültürü, İSG liderliği, etkin bir şekilde hazırlanmış güvenlik programı ve güvenlik 
performansı bileşenlerinin her birinin ayrı ayrı ele alınması ve faaliyetler sonucunda bir bütün olarak değerlendirilmesi gerekmektedir.

\section{A. Güvenlik Kültürü}

Güvenlik kültürü, İSG’yi tehdit edebilecek davranış veya uygulamalarla, "ortak kullanım ya da etki alanında" bulunan canlıların ve/veya nesnelerin zararını en aza indirmeyi amaçlayan, İSG'ye öncelik veren algılar, inançlar, tutumlar, kurallar, roller, sosyal, teknik ve politik uygulamalarla birlikte sorumluluk hislerinin bütünü olarak tanımlanmıştır (Özkan ve Lajunen,2003:3).

WCS başarısına temel teşkil edecek güvenlik kültürünün varlığı için öncelikli olarak üst yönetimin desteği sağlanmalıdır. Yönetimin İSG konusundaki isteğini gösteren ve desteğini ortaya koyan çalışmalar, çalışanların güvenlik kültürüne uyumu ve güvenlik kültürünü benimsemeleri için iyi bir zemin oluşturmaktadır. Bu zemin üzerine yöneticiler, daha kolay bir şekilde çalışanların sorumluluklarını tanımlayabilir, alınması gerekli eğitimleri gerçekleştirebilir, ödül ve yaptırımlarla İSG sürecini takip edebilir ve güvenlik denetimlerini daha kolay gerçekleştirebilmektedir.

WCS'ye ulaşabilmesi için İSG'nin örgüt içinde birinci önceliğe sahip olması gerekliliği açık iletişim kanalları aracılığıyla her zaman vurgulanmalıdır. Sistem yaklaşımıyla tüm kademelerde güvenlik anlayışının hakim olması sağlanmalıdır. Üst düzey yöneticilerin de sadece finansal çıktılar ve işletme çıktılarıyla ilgilenmeyip, çalışma sahasına inerek ISG faaliyetlerini desteklediklerini göstermeleri gerekmektedir. Güvenli davranış bilinciyle, üst yönetimden çalışana; çalışandan da takım arkadaşlarına doğru yayılan güvenlik dalgası işletme içinde güvenlik kültürünün oluşmasına ve yerleşmesine kolaylık sağlayacaktır.

İSG amaçlarının her gün gerçeğe uyarlanarak çalışanlara aktarılabilmesi ve işletmede güvenlik kültürünün oluşturulabilmesi için tüm çalışanların katılımı olmazsa olmaz bir unsurdur. Bu nedenle İSG konusunda çalışanlar arasında iletişim kanalları açık olmalı ve çalışanlar karar verme sürecine dahil edilmelidir. Bu doğrultuda çalışanlar bireysel olarak ve/veya takım çalışmaları bünyesinde tehlike ve risk öngörüsünde bulunarak tehlikeli durum ve davranışları tespit edip, iyileştirme çalışmalarına katkıda bulunmalıdır. Buna ek olarak öğrenen örgüt yapısıyla işletmelerde örgüt öncelikleri net bir şekilde tanımlanmalıdır. Diğer taraftan prosedürlerin sağlanmasıyla güvenlik kültürü hem yazılı hem de sözel olarak işletme içerisinde var olduğu gösterilmelidir.

İşletmeler güvenlik kültürünün oluşturulmasının yanında güvenlik kültürünün sürekliliğinin sağlaması konusunda da gereken çabayı göstermelidir. Güvenlik kültürünün sürdürülebilirliği ile işletme mevcut güvenlik kültürü seviyesini değerlendirerek WCS'de en iyi olma yolunda bir üst seviyeye çıkmak için hiç durmadan çalışmaya devam etmelidir. Bu doğrultuda işletmelerin WCS seviyesine ulaşabilmek ve bu seviyenin sürekliliğini sağlayabilmek için, mevcut uygulamaları değerlendirme, revize etme ve/veya yeni uygulamaları devreye alma gibi faaliyetlerde bulunması gerekmektedir. Bu bağlamda işletmelerde esecek değişim rüzgârları, çalışanların direnç göstermelerine neden olabilmektedir. Bu 
noktada çalışanlara değişimin işletmenin ve dolayısıyla kendilerinin geleceği için önemli bir gereklilik olduğu anlatılmalıdır. Bunun için lider ve lider ruhlu çalışanların işletme içindeki fonksiyonları çok önemli bir yer tutmaktadır.

\section{B. İSG Liderliği}

İSG uygulamalarında başarının elde edilebilmesi, güvenlik kültürü ile İSG liderliğinin işletme içerisinde etkileşimli bir şekilde hayat bulmasıyla ilgilidir. En iyi şekilde yerine getirilmeye çalışılan İSG çalışmalarının planlama, uygulama ve kontrol aşamalarında yaşanan değişim süreçlerini çalışanın ve işyerinin lehine iyi bir şekilde yönlendirmek, gerekli motivasyon çalışmalarını yaparak tüm çalışanların katılımını sağlamak ve artırmak İSG liderlerinin çalışma konularının başında gelmektedir. $\mathrm{Bu}$ çerçevede güvenlik kültürünü oluşturmaya istekli çalışanların, yasal zorunluluğun getirdiği İSG yapılanmasıyla (İSG Kurulu, İSG Komitesi, Çalışan Temsilcisi gibi) birlikte işletme içinde iyileştirme güdüsüyle çalışması gerekmektedir. Çalışanlar üzerinde bu motivasyonu sağlamak ise hem üst yönetime hem de İSG liderlerine düşmektedir.

İSG çalışmalarının başarısında, liderlik ve üst yönetimin desteğinin yanı sıra düzenli olarak gerçekleştirilen İSG eğitimlerinin de etkisi söz konusudur. İSG eğitiminin etkin bir şekilde gerçekleştirilebilmesi için, öncelikli olarak belirli bir mesleki eğitime sahip çalışanların İSG program uygulamalarına katılımı sağlanmalıdır. Burada önemli olan nokta, mesleki eğitimle birlikte İSG çalışmalarının tümleştirilerek çalışanlara aktarılmasıdır. Teorik ve uygulamalı olarak eğitim alan çalışanların, aldıkları bu eğitimin yanında üst yönetimin bu tür çalışmaları ve eğitimleri önemsediğinin farkına varmalarıyla birlikte çalışma ortamında paylaşım, motivasyon ve dolayısıyla verim artacaktır. Performansı bu anlamda iyileşen çalışanların buna ek olarak İSG deneyimi de arttırılmış olacaktır. Bunun yanında İSG eğitimlerine işletmelerin faaliyet ve fiziksel sınırları içinde bulunan tüm paydaşlarının dahil olması verilen eğitimin ve geri bildirimlerin kalitesini de artıracaktır. Böylelikle işletme ve çevresinde elde edilmek istenen güvenli iş ortamı ve anlayışı sağlanmış olacaktır.

İSG eğitimlerinin yanı sıra, davranış temelli güvenlik anlayışının hâkimiyeti için; işletmelerde güvenlik görüşmeleri, İSG Haftası (4-10 Mayıs) etkinlikleri, anons sistemleri, güvenlik kontrol takvimi uygulamaları ve sosyal medya araçlarının kullanımı gibi pekiştirici uygulamalar da gerçekleştirilmelidir. Bu uygulamalar sayesinde gün içerisinde çalışanların İSG ile ilgili farkındalıklarını sağlamak, arttırmak ve/veya ayakta tutmak mümkün olmaktadır.

\section{C. İSG Programı}

Güvenlik kültürünün varlığını sağlama ve koruma adına, etkin liderlik anlayışıyla birlikte tatmin edici sonuçlara ulaşılabilmesi için ISSG programı devreye girmektedir. ISG programını çalışanların davranış ve tutumlarını şekillendirmeye odaklanan, tüm kaza ve yaralanmaların tahmin edilebilir ve önlenebilir olduğu anlayışını hakim kılmaya çalışan, tüm çalışanların katılımı ile yönetim ve çalışanlar arasındaki bariyerleri kaldırarak çalışanların her türlü bilgi, soru ve uygulamaya dönük çalışmalarını destekleyerek İSG bilgi veri tabanıyla bütünleşen bir uygulamalar bütünü olarak tanımlamak mümkündür. Bu program hazırlanırken; 
programın, işletmenin tüm paydaşlarına ve çalışanlarına hitap etmesi, İSG'nin işletme için temel bir değer olduğunun vurgulanması ve çalışanların İSG programına uyumu için her türlü teşvikin ve desteğin verildiğinin gösterilmesi büyük önem taşımaktadır. İSG programından istenilen performansın alınabilmesi için bu hususlara ayrıca önem verilmelidir.

İSG programının etkin işlemesi için gerekli bileşenlerden biri olan İSG planı, planlama aşamasında yapılan çalışmalar sonucunda ortaya çıkmakla birlikte taşıdığı kilit önem nedeniyle ayrı olarak incelenmelidir. Çünkü başarılı bir İSG uygulaması geliştirmek için son adım, güvenlik planı oluşturmaktır. İSG planını; meslek hastalıkları, yaralanmalar ve iş kazalarına karşı eylem planı ve işyerinde İSG'ye adaptasyonu sağlamak adına yazılı kurallarla örgütün katılımını sağlayan bir plan olarak tanımlamak yanlış olmayacaktır. Bu çerçevede İSG planı; işletme çapında iletişim sayesinde temel fonksiyonel alanlardan elde edilen girdiler ile geliştirilmeli ve daha sonra, planın etkili bir şekilde uygulanmasını sağlamak için düzenli olarak gözden geçirilmelidir.

\section{D. İSG Performansı}

Bireysel farkındalığın sağlanmış olduğu güvenlik kültürü ortamında, çalışanların her birinin İSG ile ilgili faaliyetlerde liderlik rolünü üstlenmesi ve tüm çalışanların katılımıyla etkin bir şekilde uygulanan İSG programının sonuçları İSG performansını göstermektedir.

İşletmeler belirledikleri hedeflerin ne doğrultuda gerçekleştirilip gerçekleştirilmediğini performans takibi ile öğrenebilmektedir. Bu durum İSG programı ve bu program çerçevesinde gerçekleştirilen faaliyetler için de geçerlidir. İşletmelerin genel planlariyla uyum göstermek durumunda olan İSG faaliyetleri ile İSG planı uygulanırken ve/veya uyguladıktan sonra, ISG performansı çeşitli teknikler ve araçlar kullanılarak gözlemlenir ve değerlendirilir. Böylelikle işletmeler WCS hedefine dair gerekli İSG performansına ulaşabilmek için kendilerine yol gösterecek olan verileri elde edebilecektir.

İşletmelerin ihtiyaç duyduğu İSG performansını ortaya koyacak göstergelerin elde edilmesini sağlayan performans ölçüm sistemleri; proaktif ve reaktif olmak üzere iki tür göstergeyi içermektedir (Özdemir ve Topçuoğlu, 2009:32). Kaza ve hastalık istatistikleriyle elde edilen sonuçlar reaktif göstergeler; herhangi bir kaza, yaralanma ve hastalık meydana gelmeden yapılan çalışmalar ise proaktif göstergeler olarak adlandırılmaktadır (Laitinen, 2011:56). Daha ayrıntılı bir sınıflama ile İSG performansı yönlendirici, izleyici ve çıktı göstergeleri ile takip edilebilmektedir (Reiman ve Pietikäinen, 2012:1997). Literatürde çeşitli kaynaklardan derlenen WCS performans göstergelerini iş güvenliği öneri ortalaması, İSG kurullarında temsil edilen toplam işgücünün yüzdesi, meslek hastalığı oranı, işe devamsızlık oranı, İSG eğitim saati, kaza sıklık oranı, kaza olabilirlik (tekrarlama) oran1, olay oran1, yaralanma oranı ve Elmeri endeksi şeklinde siralamak mümkündür.

İSG performansının ölçülmesi için kullanılabilecek belirli göstergeler bulunmakla birlikte adı geçen performans göstergelerinin hangi değerleri alması durumunda işletmelerin dünya klasmanı seviyesinde değerlendirileceği sektörden 
sektöre değişme gösteren bir durumdur. Başka bir deyişle her bir işletmenin İSG performans göstergeleri ve dolayısıyla performans seviyesi farklılık gösterebilmektedir.

İşletmeler açısından WCS hedefine yönelik olarak ortaya konulan performans kadar bu performansın izlenmesi ve değerlendirilmesi de çok önemlidir. Performans izleme ve değerlendirmeleri sonucunda işletmeler, hem güvenlik kültürü hem de İSG liderliği için önemli geri bildirimler sağlamış olacaktır. $\mathrm{Bu}$ geri bildirimler sayesinde program boyunca yapılan doğru uygulamalar pekiştirilecek, yapılan hatalar üzerinden değerlendirmeler yapılarak önlenmesi sağlanacaktır. Böylece sürekli iyileştirme anlayışı tüm sürece yansımış ve pekişmiş olacaktır.

\section{WCS BILESSENLERININ WCS BAŞARISINA ETKISISININ İNCELENMESI ÜZERINE BİR UYGULAMA}

Hansen'in ortaya koyduğu modelden hareketle çalışmamızın amaçları, araştırmaya dahil olan işletmelerin ISG uygulamaları açısından mevcut durumunu ortaya koymak, sonrasında WCM'ye ilişkin bilgi ve tecrübeleri ile WCM stratejilerini ve WCS bileşenlerini değerlendirmek ve WCS bileşenlerinin WCS başarısına etkisini tahminleyen bir model sunabilmektir. Bu amaçlarla çalışmamız, Ege Bölgesi Sanayi Odası'nın 2012 yılı için belirlediği Türkiye'nin en büyük 500 sanayi kuruluşu listesinde yer alan işletmelerden belirli bir bölge içinde bulunan 58 işletme üzerinde uygulanmıştır. Literatürden derlenerek hazırlanan anket soruları işletme hakkında genel bilgiler, WCM ve İSG ile ilgili sorular olmak üzere üç kısımdan oluşmaktadır. İSG uygulamalarına yönelik sorulan sorulara ek olarak WCS bileşenleri için literatürden derlenen 70 ifade 5'li likert ölçeğinde (1:kesinlikle katılmıyorum, .. ,5:kesinlikle katılıyorum) değerlendirilmiştir. İşletmelerin İSG sorumlularına elektronik ortamda gönderilen anketlere 39 işletme cevap vermiş ve anket geri dönüş oranı yaklaşık olarak \% 67 olmuştur. Anket, uzmanlara yönetildiğinden reverse soru sorulmamıştır. İncelemeye alınan 39 işletme tüm soruları yanıtlamıştır. Anketin analizinde SPSS 17.0 paket programından faydalanılmıştır.

Anketin genel güvenilirliği \%93,8 olarak hesaplandığından güvenilir olduğuna ve istatistiksel analizlerin yapılabileceğine karar verilmiştir. Bileşenlerin ayrı ayrı değerlerine bakıldığında en yüksek güvenilirliği sağlayan bileşen ise "İSG programı"dır. İSG performansının \%57,3 ile orta seviyede çıkmasının nedeni ise ankete katılan işletmelerin performans göstergeleri hakkında pek bilgi vermek istememeleri olduğuna kanaat getirilmiştir.

\section{A. İşletmelerin Genel Özelliklerine Dair Anket Bulguları}

Ankete katılan işletmelerin \%41'i otomotiv, \%12,8'si gida, \%12,8'si metal ve \%33,4'ü diğer (beyaz eşya, çevre, petrokimya, pvc, kağıt) sektörlerde faaliyette bulunmaktadır. Söz konusu işletmelerin \%74,4'ü büyük ölçekli, \%20,5'i orta ölçekli ve \%5,1'i küçük ölçekli işletmeler sınıflamasında yer almaktadır. 2012 yılında yürürlüğe giren yeni KOBİ tanımlamasına göre çalışan sayısı ve satış geliri baz alındığında, ankete katılan işletmelerin \%74,4'ü büyük ölçekli işletmelerdir. Ankete katılan işletmelerin \%48,7'si organize sanayi bölgesinde faaliyette 
bulunmakta ve \%94,9'u ihracat, \%89,7'si ithalat yapmaktadır. İşletmelerin \%53,8'i OHSAS 18001 belgesine sahipken, \%17,9'u bu belgeyi hazırlama aşamasında bulunmakta ve \%28,2'sinin ise OHSAS belgesi bulunmamaktadır.

\section{B. WCM'ye Yönelik Bulgular}

Ankete katılan işletmelerden yoğun ve sert rekabet ortamında faaliyette bulunurken gerçekleştirmeye çalıştıkları rekabet önceliklerini, önem sırasına göre sıralamaları istenmiştir. Değerlendirme sonucunda sıralama; kalite, maliyet, hız, yenilikçilik, hizmet, esneklik, dağıtım şeklinde olmuştur. Bu sonuç 2001 yılında Gilgeous ve Gilgeous'un İngiltere'de ve 2012 y1lında Güney Hindistan'da Murugesan ve diğerlerinin yaptığı çalışmaların sonuçlarına benzer olarak en önemli rekabet önceliğinin kalite olduğunu göstermektedir. Rekabet önceliklerinin uygulanması ile ilgili literatürden derlenen üç modelden (ödünleşim-sinerjikentegre) en çok uygulanan model \%53,8 ile sinerjik model olmuştur. Elde edilen bu sonuçla ankete dahil olan işletmelerin dünya klasmanında üretimin metodolojisine uygun olarak tüm rekabet önceliklerinde eş zamanlı olarak optimize etmeye çalıştıklarını söylemek mümkündür.

Ankete katılan işletmelerin \%64,1'i WCM hakkında bilgi sahibi olduğunu, \%87'si ise İSG ile ilgili çalışmalar yaptıklarını belirtmişlerdir. Müşteri hizmet seviyesi ölçümü ve takibi, WCM değerlendirme kriterleri içerisinde en önemli sırayı almaktadır. Ankete katılan işletmelerin \% 61,5'i bu değeri takip etmektedir. Dolayısıyla WCM hakkında bilgi sahibi olan işletmeler müşteri hizmet seviyelerini ölçmektedir.

Ayrıca işletmeler müşteri hizmet seviyesi ölçüm kriterleri olarak mükemmel dağıtım, doğru bilgilendirme, ISO 9001 sevkiyat performansına göre anket sistemi, birebir görüşme, müşteri memnuniyet anketi, kalite, hız, maliyet, teknoloji, y1llık raporlama, ISO 10002 Müşteri Şikayetleri Yönetimi, tedarikçi değerlendirme sistemi, kalite ve lojistik performans göstergeleri, satış, İSG, iletişim, teklif durumu, düzeltici faaliyet gibi değerleri belirtmişlerdir. Anket cevaplarına göre işletmeler müşteri hizmet seviyeleri farklı kriterlere göre değerlendirilmekte olup, bu kriterlerin kullanım oranları \%60 ile \%100 arası değişmektedir.

Belirttikleri müşteri hizmet seviyesine göre 39 işletmeden sadece 3 işletme dünya klasmanında yer almaktadır. Bu konumlandırmalarını doğrulayabilmek adına işletmelerin kendilerini WCM kapsamında 5'li likert ölçeğinde (zayıf (1) orta (2) - iyi (3) - çok iyi (4) - mükemmel (5)) değerlendirmeleri istenmiştir. Dünya klasmanında üretim yapan işletmelerin, müşteri hizmet seviyesini ölçmeleri temel alındığından, anketimize dahil olan işletmelerin WCM değerlendirmeleri ile müşteri hizmet seviyeleri arasındaki ilişkiye bakılmış ve aşağıdaki tahmin modeli elde edilmiştir.

$\mathbf{X}_{\mathbf{1}}=$ müşteri hizmet seviyesi

$$
\widehat{\boldsymbol{Y}}_{\mathrm{WCM}}=-2,746+0,064 \mathrm{X}_{1}
$$

Pozitif ve güçlü bir ilişkinin olduğunu gösteren regresyon tahmin modeli, işletmelerin WCM değerlendirmesinin \%27'sini açıkladı ̆̆ı görülmüştür. WCM değerlendirmesinin \%27'lik açılama gücüne sahip olan müşteri hizmet seviyesi 
dışında, WCM değerlendirmesini etkileyen faktörlerin varlığı da söz konusudur. $\mathrm{Bu}$ faktörlerin tespiti ve WCM değerlendirmeleri üzerindeki etkilerinin incelenmesi gelecek çalışmalara alternatif bir konu olarak önerilmektedir.

\section{ISG Uygulamalarına Yönelik Bulgular}

Ankete katılan işletmelerin \%59'u İSG'yi yasaya bağlı bir zorunluluk olarak görmekte iken, \%28,2'si yönetim anlayışlarının bir parçası; \%12,8'i ise hem yasaya hem de yönetime dayalı olarak ele almaktadır. Bu sonuç 2013 Haziran ayında yürürlüğe giren 6331 Sayılı İs Sağlığı ve Güvenliği Kanunu ile birlikte işletmelerin İSG çalışmalarının farkına vardığını ve bir zorunluluk olarak algıladıklarını ortaya koymaktadır. Hâlbuki işletmelerin İSG' yi yasanın getirdiği mecburi bir uygulama olarak algılamadan, işletmenin temel değerleri arasında öncelikli olarak ele alması işletmeleri bu uygulamalarda başarıyı sağlayıcı öncül bir faktör olacaktır.

Söz konusu işletmelerin \%84,6'sı İSG çalışmalarını takip edebilmek için bilgi sistemi kullanmaktadır. Günümüz işletmelerinin büyük bir çoğunluğu yönetim ve izleme işlemlerini bilgi sistemleriyle gerçekleştirmektedir. Bu noktada önemli olan konu, gerçekleşen her olayın zamanında kayıt altına alınarak güvenilir bir veri kaynağı sağlamaktır. Buradan elde edilecek bilgiler ışığında yapılacak önleyici çalışmalar İSG uygulamalarını başarıya ulaştıracaktır. Bilgi sistemi kullanan işletmelerin İSG'ye dair yaptıkları çalışmaların \%62'si düzeltici faaliyet ve eğitim takibine ilişkin olduğu görülmüştür.

İSG uygulamalarının etkin bir şekilde gerçekleştirilebilmesi bu çalışmaları yapacak personelin uygun bir organizasyon yapısı içinde yer almasını gerektirir. Ankete cevap veren işletmelerin \%85'inde İSG Kurulu mevcuttur. Buna ek olarak işletmelerden sadece iki tanesinde İSG Kurulu-İSG Komitesi-İSG Alt Komitesi şeklinde bir yapılanma söz konusudur. $\mathrm{Bu}$ sonuca göre işletmelerin İSG uygulamalarının değerlendirilmesinin üst yönetim kademesinde gerçekleştiği, tüm çalışanlara yayılımın söz konusu olmadığını söylemek yanlış olmayacaktır. Başka bir ifade ile çalışanların İSG ile ilgili uygulamalara katılımı tam olarak sağlanamamıştır. ISG uygulamalarına katılımı sağlamak adına tüm çalışanların kendilerini rahatlıkla ifade edecekleri ortamlar yaratılmalı ve ilgili araçların kullanımı teşvik edilmelidir. Ankete katılan işletmeler, İSG uygulamalarından en çok (\%85) İSG tespit ve öneri defterini kullanmaktadır. Standart İSG uygulamaları dışında işletmeler; sarı-beyaz kart uygulaması, kök-neden analizi, saha kontrolü, tek nokta eğitimleri ve hatta tiyatro aracılığıyla bile bu uygulamaların gerçekleştirilmekte olduklarını da belirtmişlerdir.

Ankete katılan işletmelerin kendilerini WCM ve ISG uygulamaları açısından değerlendirmeleri sonucunda; işletmelerin \%5,1'i kendisini WCM uygulamaları açısından, \%15,4'ü de kendisini İSG uygulamaları açısından mükemmel olarak değerlendirmiştir. WCM kriterlerine göre elde ettiğimiz ve yukarıda gösterilen tahmin modeli ile ortaya çıkardığımız sonuçlar anketimize dahil olan ve kendilerini mükemmel olarak ifade eden işletmelerin mükemmel olmadığını, en fazla "çok iyi” seviyesinde olabileceklerini göstermiştir. 
Ankete cevap veren işletmelerden 2010, 2011 ve 2012 yılları için takip ettikleri performans göstergelerini belirtmeleri istenmiştir. Bu soruya verilen cevaplar genel olarak değerlendirildiğinde, performans göstergelerinin farkında olan işletmelerin bu performans göstergelerini 2010 y1lından itibaren dikkate almaya başladıkları görülmektedir. Göstergelerde üç yıllık dönem içinde genel olarak azalma seyri gözlemlenmiştir. Göstergelerin standart ve ortak bir hesaplanma şeklinin olmayışı ya da aynı şekilde hesaplanmayışı işletmeleri gösterge hesaplama konusunda zorlamıştır. Ankete katılan bazı işletmeler ise bu göstergelerden bir haberdir. Bu işletmelerin çoğu 6331 Sayılı İş Sağlığı ve Güvenliği Kanunu ile birlikte, İSG'nin yeni farkına varmış ve birçok göstergeyi yeni kayıt altına almaya başlamıştır. Genel olarak işletmelerde takip edilen göstergelerin kayıt altına alınmasında, dokümantasyonunda ve bunun sürekliliğinin sağlanmasında sorun yaşanmaktadır.

\section{WCS Bileşenlerine Yönelik Bulgular}

Dünya klasmanında iş sağlığı ve güvenliği başarısını elde edebilmek için Hansen'in modelinde yer alan WCS bileşenlerine dair bir araya getirilmiş ifadeler arasındaki ilişkileri en yüksek derecede temsil edecek az sayıda faktörü elde etme amacıyla anket sonuçlarına faktör analizi yapılmıştır. Toplamda 70 tane olan WCS bileşen ifadelerinden faktör yükü 0,50'nin altında olanların elenmesi sonucunda 60 ifade üzerinde çalışılmıştır. 60 ifade İSG değerlendirmelerinin \%89,16'sını açıklamaktadır. Güvenlik kültürü, İSG liderliği ve İSG programı ile ilgili yapılan faktör analizi, KMO testi sonucuna göre anlamlı çıkmıştır. Performans için yapılan faktör analizinden KMO testi sonucunda elde edilen 0,392 değeri 0,40'ya yakın olduğu için kabul edilebilir bir seviyededir. Ancak bu değerin diğer KMO testi değerlerinden düşük çıkmasının nedenleri olarak anket cevaplayıcılarının bu konuda bilgi vermek istememeleri ve ifade sayısının azlığını söylemek mümkündür.

Yapılan faktör analizi sonucu WCS bileşen ve alt bileşenlerini açıklama yüzdeleri Tablo 2'de gösterilmiştir. Analize dahil olan ifadeler, güvenlik kültürünün \% 76,9'unu açıklamış ve eğitim, farkındalık, süreç, iyileştirme anlayış1 ve çalışan katılımı alt başlıkları altında toplanmıştır. Belirtilen alt başlıklardan güvenlik kültürü için en önemli olan faktör eğitim olmuştur. Üst yönetimin desteği ile birlikte yılda en az iki kere verilecek olan İSG eğitimleri, çalışanların İSG farkındalıklarını sağlayacak ve güvenlik kültürü için gerekli zemini oluşturacaktır.

İkinci WCS bileşeni olan İSG liderliği için yapılan faktör analizi sonucu analize dahil olan ifadeler, İSG liderliğinin \%75,55'ini açıklama yeteneğine sahiptir. İfadeler sürekli iyileştirme, karar alma, takım çalışması, iletişism, kriz ve direnç alt başlıkları altında toplanmıştır. Belirtilen alt başlıklardan ISGG liderliği için en önemli olan faktör sürekli iyileştirme olmuştur. Kalite yönetimi ve sürekli iyileştirme uygulamalarını benimseyen işletmelerde takım halinde çalışma, çalışan katılımı, aktif liderler ve üst yönetim ile sürekli işbirliği söz konusudur. WCS başarısı için gerekli İSG liderliği fonksiyonlarını sağlayacak işletme ortamı da bu şekilde sağlanır. 
Üçüncü WCS bileşeni olan İSG programı için yapılan faktör analizi sonucu analize dahil olan ifadeler, İSG programının \%75,31'ini açıklama yeteneğine sahiptir. İSG programı ifadeleri için yapılan faktör analizi sonucunda; plan, denetim ve organizasyon alt başlıkları oluşmuştur. Belirtilen alt başlıklardan hem İSG programı için hem de WCS alt bileşenleri içinde en önemli olan faktör plan olmuştur. İSG komitesi sayesinde aktif olarak uygulamaya yönelik hazırlanan eğitim programları ile çalışanlara temin edilen ve kullanımı sağlanan kişisel koruyucu donanımlar ISG programının vazgeçilmez ve başarıya götüren temel yapıtaşlarıdır. Güvenlik kültürü ve İSG liderliği sayesinde elde edilen bu yapıtaşları birbirini tamamlayarak İSG programının istenen performans değerlerine ulaşmasına yardımcı olacaktır.

Tablo 2: WCS Bileşen ve Alt Bileşenlerini Açıklama Yüzdeleri

\begin{tabular}{|c|c|c|c|c|c|c|}
\hline $\begin{array}{l}\text { WCS } \\
\text { BİLESENLERİ }\end{array}$ & \multicolumn{6}{|c|}{ WCS Alt Bileşenleri (\%) } \\
\hline \multirow{2}{*}{$\begin{aligned} K \ddot{U} L T \ddot{U} R & \\
& \% 76,9\end{aligned}$} & Eğitim & Farkında & Süreç & İyileştirme & \multicolumn{2}{|c|}{ Çalışan Katılımı } \\
\hline & 33,54 & 13,13 & 10,9 & 10,1 & \multicolumn{2}{|r|}{9,24} \\
\hline \multirow[t]{2}{*}{ LIDERLIK } & $\begin{array}{l}\text { Sürekli } \\
\text { İyileştirme }\end{array}$ & $\begin{array}{l}\text { Karar } \\
\text { Alma }\end{array}$ & $\begin{array}{l}\text { Takım } \\
\text { Çalışmas }\end{array}$ & İletişim & $\begin{array}{l}\text { Engell } \\
\text { er }\end{array}$ & Direnç \\
\hline & 32,017 & 11,29 & 9,56 & 8,66 & 7,6 & 6,44 \\
\hline \multirow{2}{*}{$\begin{array}{r}\text { PROGRAM } \\
\% 75,31\end{array}$} & Plan & $\begin{array}{l}\text { Bilgi } \\
\text { Sistemi }\end{array}$ & \multicolumn{4}{|c|}{ Organizasyon } \\
\hline & 53,83 & 12,1 & \multicolumn{4}{|c|}{9,4} \\
\hline PERFORMANS & \multicolumn{6}{|c|}{ 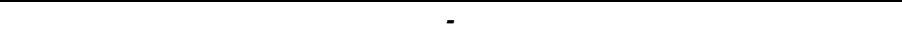 } \\
\hline
\end{tabular}

Güvenilirliği yüksek çıkan anket sonuçlarına göre Hansen'in WCS başarı modelinin en önemli bileşeni "ISG programı" olmuştur. Alt bileşenler bazında değerlendirildiğinde ise "eğitim", "sürekli iyileştirme" ve "plan" en önemli alt bileşenler olarak tespit edilmiştir. Sürekli iyileştirme anlayışı ile birlikte sıfır kaza ve sıfır anormallik amacı doğrultusunda işletmelerin WCS bileşenlerinden ISG Programına gereken önemi ve özeni göstermeleri gerekmektedir.

\section{E. WCS Bileşenlerinin WCS Başarısı Üzerine Etkisinin İncelenmesi}

Faktör analizinden çıkan anlamlılığa bağlı olarak toplamda 60 ifade (Güvenlik kültürü, İSG liderliği, İSG programı ve performans) için ayrı ayrı İSG öz değerlendirme ile ilgili regresyon analizine bakılarak alt bileşenlere ait tahmini regresyon modelleri elde edilmiş ve Tablo 3 'te gösterilmiştir. 
Tablo 3: WCS Başarısında Rol Alan Bileşenler ve İSG Öz Değerlendirmeleri İçin Regresyon Modelleri

\begin{tabular}{|c|c|c|c|}
\hline $\begin{array}{l}\text { WCS } \\
\text { Bileşenle } \\
\text { ri }\end{array}$ & $\mathbf{R}$ & $\begin{array}{l}\text { WCS Bileşenlerine Bağlı } \\
\text { ISG Değerlendirme } \\
\text { Regresyon Modeli }\end{array}$ & İfade \\
\hline $\begin{array}{c}\text { Kültür } \\
\left(\widehat{\boldsymbol{Y}}_{\mathbf{K}}\right)\end{array}$ & 0,621 & $\widehat{\boldsymbol{Y}}_{\mathbf{K}}=-0,087+0,767 \mathrm{X}_{1}$ & $\begin{array}{l}\mathrm{X}_{1}=\mathrm{K}_{14}: \text { Üst yönetim İSG uygulamaların } 1 \\
\text { desteklemektedir. }\end{array}$ \\
\hline $\begin{array}{l}\text { Liderlik } \\
\qquad\left(\widehat{\boldsymbol{Y}}_{\mathrm{L}}\right)\end{array}$ & 0,364 & $\widehat{\boldsymbol{Y}}_{\mathbf{L}}=1,915+0,379 \mathrm{X}_{1}$ & $\begin{array}{l}\mathrm{X}_{1}=\mathrm{L}_{16} \text { : Firmamızda İSG için sistematik } \\
\text { bir yaklaşım söz konusudur. }\end{array}$ \\
\hline $\begin{array}{c}\text { Program } \\
\left(\widehat{\boldsymbol{Y}}_{\mathrm{P}}\right)\end{array}$ & 0,521 & $\widehat{\boldsymbol{Y}}_{\mathbf{P}}=-0,025+0,757 \mathrm{X}_{1}$ & $\begin{array}{l}\mathrm{X}_{1}=\mathrm{P}_{17}: \text { Acil durum tatbikatları } \\
\text { yapılmaktadır. }\end{array}$ \\
\hline $\begin{array}{l}\text { Performa } \\
\text { ns }\left(\widehat{\boldsymbol{Y}}_{\mathrm{G}}\right)\end{array}$ & 0,593 & $\begin{array}{c}\widehat{\boldsymbol{Y}}_{\mathbf{G}}= \\
0,565+0,487 \mathrm{X}_{1}+0,237 \mathrm{X}_{2}\end{array}$ & $\begin{array}{l}\mathrm{X}_{1}=\mathrm{G}_{4} \text { : Tehlikeli davranışlar ve tehlikeli } \\
\text { durumların sayıs1 rapor edilmektedir. } \\
\mathrm{X}_{2}=\mathrm{G}_{2} \text { : Büyük kaza önleme politika } \\
\text { belgemiz mevcuttur. }\end{array}$ \\
\hline
\end{tabular}

Faktör analizinde anlamlı çıkan 60 ifadeden güvenlik kültürü ifadeleri ile İSG öz değerlendirmeleri arasında yapılan regresyon analizi; belirtilen değişkenler arasında pozitif ve orta düzeyde güçlü bir ilişki olduğunu saptamıştır. İSG değerlendirmelerini \%38,5 ile açıllama gücüne sahip olan güvenlik kültürü ifadelerinden "Üst yönetim ISG uygulamaların desteklemektedir." en önemli ifade olmuştur. Güvenlik kültürünün tesis edilebilmesi ve sürekliliğinin sağlanabilmesi için üst yönetimin desteğinin büyük bir öneme sahip olduğunu destekleyen bir sonuç olarak ortaya çıkmıştır. Bu sonuç işletmelerde üst yönetimin desteği olmadan güvenlik kültürünün ve dolayısıyla İSG çalışmalarının başarısının mümkün olamayacağını göstermektedir.

İşletmelerin mevcut İSG uygulamaları açısından öz değerlendirmeleri ile İSG liderliği ifadeleri arasında orta seviyede bir ilişki söz konusudur. İSG değerlendirmelerini \%13,2 ile açıklama gücüne sahip olan İSG liderliği ifadelerinden "Firmamızda ISG için sistematik bir yaklaşım söz konusudur." en önemli ifadedir. İSG ile ilgili farkındalığı sağlamak ve işletmede İSG çalışmalarını tam anlamıyla gerçekleştirebilmek için takım çalışması, çalışan katılımı ve sistematik yaklaşım büyük öneme sahiptir. Bu üç unsuru bir araya getirme ve işlerliğini sağlama, İSG liderliğinin bir fonksiyonudur. Ayrıca sürekli iyileştirme ve kalite anlayışının işletmede yerleşmesi açısından toplam kalite çalışmalarında bulunmak ve İSG süreçleri içerisinde aktif olarak yer almak İSG liderliğini pekiştirmek açısından incelendiğinde İSG uygulamaları için uygun ve sağlam bir zemin sağlayacaktır.

İşletmelerin mevcut İSG uygulamaları açısından öz değerlendirmeleri ile İSG programı ifadeleri arasında orta seviyede bir ilişki söz konusudur. İSG değerlendirmelerini \%27 ile açıklama gücüne sahip olan İSG programı ifadelerinden "Acil durum tatbikatlar yapılmaktadır." en önemli ifadedir. Gerçekleştirilen eğitimlerin teoride kalmayarak hayatın her anında 
gerçekleştirilebilir ve mevzu bahsin insan hayatı olduğu hususunun, İSG programının vazgeçilmez bir temel değeri olarak ele alınması gerekmektedir. Verilen eğitimler ve edinilen bilgi ve becerilerin gerçek yaşamın her anına bilinçli bir şekilde yerleştirilmesi firsatını sunan acil durum tatbikatları da bu anlamda gereken hassasiyetin gösterilmesini sağlayacaktır.

İşletmelerin mevcut ISG uygulamaları açısından öz değerlendirmeleri ile İSG performansı ifadeleri arasında orta seviyede bir ilişki söz konusudur. İSG değerlendirmelerini \%35,1 ile açıklama gücüne sahip olan ISG performans1 ifadelerinden "Tehlikeli davranışlar ve tehlikeli durumların sayısı rapor edilmektedir." ve "Büyük kaza önleme politika belgemiz mevcuttur." en önemli ifadeler olarak tespit edilmiştir. Etkin liderlik anlayışıyla tesis edilen güvenlik kültürüyle birlikte uygulanan İSG programları, performans göstergelerinin takibini gerektirmektedir. ISG performansının izlenebilmesi için kayıt ve raporlama yeteneğinin gelişmesi öncelikli koşul olarak sayılabilmektedir. Yapılan kayıtlar ve takip edilen performans göstergeleri ile yapılan çalışmaların amacına ulaşıp ulaşamadığı izlenmektedir. Performans göstergelerinin takip edilerek kayıt altına alınması ve gerekli standartları karşılıyor olması, büyük kaza önleme politikasının bir alt bileşeni olarak ifade edilmekte ve işletmelerin WCS başarısını elde edebilmek için tüm süreçleri kontrol altında tutabilmesinin gerektiğini göstermektedir.

\section{SONUÇ}

Yapılan analizler sonucunda, WCS bileşenleri ile İSG öz değerlendirme arasındaki ilişkiyi gösteren tahmin modellerinde yer alan ve Tablo 3 'te belirtilen bağımsız değişkenlerin $\left(\mathrm{K}_{14}, \mathrm{~L}_{16}, \mathrm{P}_{17}, \mathrm{G}_{2}, \mathrm{G}_{4}\right)$ ISG öz değerlendirmeleri üzerine etkileri incelenmiş ve şu tahmin modeli elde edilmiştir:

$$
\widehat{\boldsymbol{Y}}_{\text {isG }}=-1,042+0,586 \mathrm{X}_{1}+0,217 \mathrm{X}_{2}+0,294 \mathrm{X}_{3}
$$

$$
\begin{array}{lll}
\mathrm{X}_{1}=\mathrm{K}_{14} \text { :Üst yönetim İSG } & \begin{array}{l}
\mathrm{X}_{2}=\mathrm{G}_{2} \text { :Büyük kaza } \\
\text { uygulamalarını }
\end{array} & \mathrm{X}_{3}=\mathrm{L}_{16} \text { :Firmamizda } \\
\text { desteklemektedir. } & \text { belgemiz mevcuttur. } & \begin{array}{l}
\text { İSG için sistematik bir } \\
\text { yaklaşı söz konusudur. }
\end{array}
\end{array}
$$

İSG öz değerlendirme tahmin modelinde belirtilen bağımsız değişkenlerle İSG değerlendirmeleri arasında güçlü ve pozitif bir ilişki söz konusudur. Bu değişkenlerin İSG değerlendirmelerini açıklama gücü \%57'dir. WCS bileşenleri ayrı ayrı değerlendirildiğinde, WCS bileşenlerinin İSG değerlendirmelerini açıklama gücü için yeterli anlam ifade edemezken; bir araya geldiklerinde sinerji yaratarak, WCS'nin başarısında rol oynayan değişkenleri daha iyi açıklama yeteneği göstermişlerdir. Tahmin modeline en büyük katkı1 "Üst yönetim isG uygulamalarını desteklemektedir" ifadesi yapmıştır.

İşletmede WCS'nin başarılı bir şekilde sağlanabilmesi için, üst yönetimin çalışanlarına karşı açık ve net olması birinci koşuldur. İSG'nin neden gerekli olduğunu, nasıl uygulanacağını, uygulanmazsa nelerin gerçekleşeceğini, çalışanlara tüm boyutlarıyla anlatmak ve benimsetmek güvenlik kültürünün ve sonrasında uygulanacak İSG programlarının etkililiğini sağlayacaktır. İSG ile ilgili 
her şeyin herkesin anlayacağı bir dille açıkça belirtilmesi, hiçbir yoruma veya soruya işaret etmeyecek şekilde dokümante edilip, benimsetilmesi gereklidir. $\mathrm{Bu}$ çalışmaların yapılabilmesi için uygun ortamı sağlamak ve gerekli desteği vermek üst yönetime düşmektedir. Sonuç olarak işletmede WCS'nin başarısı için; WCS bileşenlerinin sağlanması ve işlerliğinin kazandırılması, üst yönetimin desteğine bağlıdır.

$\mathrm{Bu}$ çalışmayla birlikte dünya klasmanında üretim kapsamında İSG uygulamaları ve WCS bileşenleri, ülkemiz literatüründe ilk kez değerlendirilmiştir. Küçük bir örneklemde değerlendirmiş olduğumuz WCS bileşenlerinin WCS başarısına etkisinin ülke genelinde geniş kapsamlı bir araştırma projesi olarak incelenmesini ve WCS başarısı için WCS bileşenlerinin sektörler bazında ayrı ayrı değerlendirilmesini gelecek çalışmalar için önermek mümkündür.

\section{KAYNAKÇA}

Creatıve Safety Supply. (2010). “Creative Safety Supply 6S: A User's Guide”. Creative Safety Supply http://www.creativesafetysupply.com/6S-guide.html (14.02.2011)

Cua, K. O., Mckone, K. E. ve Schroeder, R. G. (2001). Relationships Between Implementation of TQM, JIT, and TPM and Manufacturing Performance. Journal of Operations Management(19), 675-694. doi:10.1016/S0272-6963(01)00066-3

Flynn, B. B., Schroeder, R. G. ve Flynn, E. J. (1999). World Class Manufacturing: An Investigation of Hayes and Wheelwright's Foundation. Journal of Operations Management, 17, 249-269. doi:10.1016/S0272-6963(98)00050-3

Fullerton, R. R. ve Mcwatters, C. S. (2004). An Empirical Examination of Cost Accounting Practices Used In Advanced Manufacturing Environments. Advances in Management Accounting, 12, 85-113. http://www.emeraldinsight.com/doi/abs/10.1016/S1474-7871(04)12004-2

Gilgeous, V., \& Gilgeous, M. (2001). A Survey to Assess The Use of a Framework for Manufacturing Excellence. Integrated Manufacturing Systems, $12 \quad$ (1), 48-58. http://www.emeraldinsight.com/doi/abs/10.1108/09576060110361537?.journalCode=ims

Hansen, L. L. (2005, Mayıs 25). "Stepping Up to Operational Safety Excellence”. Speaking of Safety Excellence: http://www.12hsos.com/publications_books_larry_hansen.html (28.06.2012)

Haynes, A. (1999). Effects of World Class Manufacturing on Shop Flor Workers. Journal of $\begin{array}{llll}\text { European } & \text { Industrial } & \text { Training, } & \text { 300-309. }\end{array}$ http://dx.doi.org/10.1108/03090599910284678

Higbee, G. A. (2002). Breaking The Cycle of Risky Behaviour. Higbee Associates: http://www.higbeeandassociates.com/articles/breaking-cycle2.pdf (28.11.2012)

Laitinen, H. (2011). “Elmeri-İSG Performans İzleme Yöntemi”. ECBOHS Projesi Çalıştayı- AB Uygulamaları Perspektifinde Issletmelerde İ̧ Sağlı̆̆ ve Güvenliği. Zonguldak: MESS.

Lind, J. (2001). Control in World Class Manufacturing- A Longitudinal Case Study”. Management Accounting Research(12), 41-74. doi:10.1006/mare.2000.0148

Leeman, J. E. (2007, 06). Punturing the Myth of World Class Safety. Industrial Safety \& Hygiene News, s. 31-37. http://www.ishn.com/articles/87004-puncturing-the-myth-of-world-class$\underline{\text { safety }}$

Mapes, J., New, C. ve Szwejczwski, M. (1997). Performance Trade-offs in Manufacturing Plants. International Journal of Operations \& Production Management, 17(10), 1020-1033. http://dx.doi.org/10.1108/01443579710177031

Maskell, B. H. (1991). Performance Measurement for World Class Manufacturing A Model For American Companies. http://books.google.com/ (12.12.2010)

Mcleod, J. R. (2008). World-Class Manufacturing-A Balancing Act. Master Brewers Association of the Americas Technical Quarterly, 45(1), 24-31. http://www.mbaa.com/publications/tq/tqPastIssues/2008/Abstracts/TQ-45-1-0024.html 
E. T. Tepekule \& Ş. Gümüşoğlu / Dünya Klasmanında Üretim Kapsamında İs Sağllğg ve Güvenliği Çalışmalarına Yönelik Bir Model Önerisi ve Uygulama

Mishra, R. P., Anand, G. ve Kodali, R. (2006). Development of A Framework For World-Class Maintenance Systems. Journal of Advanced Manufacturing Systems, 5(2), 141-165. doi:10.1016/j.procir.2014.07.174

Murugesan, T. K., Kumar, B. S., \& Kumar, M. S. (2012). Competitive Advantage of World Class Manufacturing System (WCMS) - A Study of Manufacturing Companies in South India. European Journal of Social Sciences, 29(2), 295-311. http://www.europeanjournalofsocialsciences.com/issues/EJSS_29_2.html

Mylnek, P., Vonderembse, M. A., Rao, S. S. ve Bhatt, B. J. (2005). World Class Manufacturing :Blueprint for Success. Journal of Business and Management, 11, 7-24. https://www.highbeam.com/doc/1P3-1078199321.html

Özdemir, Ş. ve Topçuoğlu, H. (2009). İş Sağlığı ve Güvenliği Performans Ölçümü ve İzleme. $\begin{array}{llrl}\text { Mühendis verina, } & \text { 50(592), }\end{array}$ http://www.mmo.org.tr/resimler/dosya_ekler/4525c362b0e8ff3_ek.pdf?dergi=536

Özkan, T., \& Lajunen, T. (2003). Güvenlik Kültürü ve İklimi. PIVOLKA, 2(10), 3-4. http://www.elyadal.org/pivolka/10/PiVOLKA_10_01.pdf

Reiman, T. ve P1etıkäınen, E. (2012). Leading Indicators of System Safety-Monitoring and Driving the Organizational Safety Potential. Safety Science(50), 1993-2000. doi:10.1016/j.ssci.2011.07.015

Roth, A. V. ve Miller, J. G. (1992). "Success Factors in Manufacturing". Business Horizons, 35(4), 73-81.

http://www.business.uzh.ch/professorships/som/stu/Teaching/FS10/MA/som/Roth Miller _1992_strategy.pdf

Rubrich, L. ve Watson, M. (2004). Implementing World Class Manufacturing Includes Lean Enterprise. Fort Wayne,Indiana: WCM Associates.

Sakamoto, S. (2010). Beyond World-Class Productivity Industrial Engineering Practice and Theory. NewYork: Springer.

Shingo, S. (1989). A Study of the Toyota Production System From an Industrial Engineering Viewpoint. New York: Productivity Press.

Steinbacher, H. R. ve Steinbacher, N. L. (1993). TPM for America: What It Is and Why You Need It. Portland, Oregon: Productivity Press.

Sun, H., Yam, R. ve Wai-Keung, N. (2003). The Implementation and Evaluation of Total Productive Maintenance (TPM) - An Action Case Study in a Hong Kong Manufacturing Company. International Journal Adv. Manufacturing Technology (22), 224-228. Doi:10.1007/s00170002-1463-3

Voss, C. A. (1995). Alternative Paradigms for Manufacturing Strategy. International Journal of $\begin{array}{llll}\text { Operations \& Production } \quad \text { Management, } & \text { 15(4), }\end{array}$ http://dx.doi.org/10.1108/01443579510083587 


\section{SUMMARY}

The approach, which aims at becoming the best in every application and operation realizing every strategy that it has at a perfect level, has been referred to as World Class Manufacturing (WCM). The synergic effect of WCM inherent in application and strategies will be helpful in taking businesses' strength to the desired level in the current competitive environment. For businesses in applications of Occupational Health and Safety (OHS) to perform at the top level will contribute to become the best, taking one step forward from its competitors. In this sense, Larry Hansen's model, which defines the success of World Class Safety (WCS) as the function of safety culture, operational leadership, safety program and performance, has been a reference point for this study. Taking this model as the basis, in this study, it is aimed to scrutinize the effect of WCS constituents' in a certain area of the businesses from the list of top 500 industrial firms in Turkey set for the year 2012 by the Aegean Region Chamber of Industry.

In this study, the information about World Class Manufacturing has been given and the applications of Occupational Health and Safety, considered as the first priority, which are evaluated within the framework of World Class Manufacturing (WCM) and the components of the suggested model have been scrutinized to reveal the effects of these c components over the success of Occupational Health and Safety (OHS) efforts.

As it depends on the human factor to achieve WCM strategies in the real sense, the source and the result of all applications is man. When considered from this perspective, WCS practices mean fixtures for businesses that want to take their places in the world-class quality and it is one of the applications they need to care about the most. Because the respect and value shown for employees in the output of each system and the processes used in the company shows itself as quality. In this sense, protecting to guarantee the health and safety of employees and the working environment; and expressing respect for employees is very important. The planned work to be done in order to create safe working environment and to avoid the adverse conditions which may damage employees, work or workplace resulting from various reasons is called world class safety applications.

Businesses must catch excellence in OHS activities in order to achieve its business objectives in the WCS. To do so, providing the physical and organizational environment on behalf of the businesses to ensure the full realization of the prerequisite OHS activities, and at this point, the employees who have the understanding to be the best and who have the properties of participant and leadership are required. Businesses should apply the program set for the desired performance, by acting together with their employees in accordance with environment. These programs should include employees and work to support all kinds of systems used.

The approach, which aims at becoming the best in every application and operation realizing every strategy that it has at a perfect level, has been referred to as World Class Manufacturing (WCM). The synergic effect of WCM inherent in 
application and strategies will be helpful in taking businesses' strength to the desired level in the current competitive environment. For businesses in applications of Occupational Health and Safety (OHS) to perform at the top level will contribute to become the best, taking one-step forward from its competitors. In this sense, Larry Hansen's model, which defines the success of World Class Safety (WCS) as the function of safety culture, operational leadership, safety program and performance, has been a reference point for this study. Taking this model as the basis, in this study, it is aimed to scrutinize the effect of WCS constituents' in a certain area of the businesses from the list of top 500 industrial firms in Turkey set for the year 2012 by the Aegean Region Chamber of Industry.

There is a moderate strong and positive relationship between the independent variables specified in OHS self-assessment model and the OHS assessments. The explanatory power of these variables in the assessment of OHS was 57\%. When WCS components are evaluated separately, they cannot express meaning sufficient to evaluate the explanatory power of OHS; when they come together, however, by creating synergy, they showed a better ability in explaining the variables that play a role in the success of WCS. The biggest contribution to the forecasting model is the statement "The Senior management supports the OHS practices."

With this study, within the scope of world-class manufacturing, safety practices and WCS components have been evaluated for the first time in the literature of our country. The examination of the impact of the components of WCS on the success of WCS, in which we have evaluated a small sample, can be suggested as a comprehensive research project across the country for future studies, assessing the components of WCS based on the assessment of individual sectors separately for the success of WCS. 